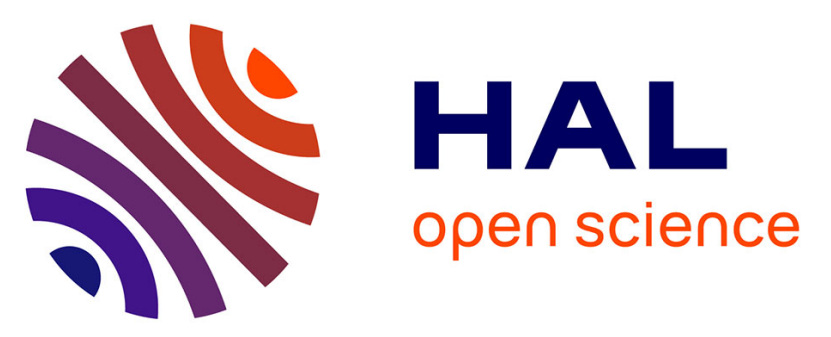

\title{
Copper stress proteomics highlights local adaptation of two strains of the model brown alga Ectocarpus siliculosus
}

Andrés A Ritter, Martin Ubertini, Sarah Romac, Fanny Gaillard, Ludovic Delage, Aaron Mann, J. Mark Cock, Thierry Tonon, Juan A. Correa, Philippe Potin

\section{To cite this version:}

Andrés A Ritter, Martin Ubertini, Sarah Romac, Fanny Gaillard, Ludovic Delage, et al.. Copper stress proteomics highlights local adaptation of two strains of the model brown alga Ectocarpus siliculosus. Proteomics, 2010, 10 (11), pp.2074 - 2088. 10.1002/pmic.200900004 . hal-01925564

HAL Id: hal-01925564

https://hal-univ-rennes1.archives-ouvertes.fr/hal-01925564

Submitted on 19 Nov 2018

HAL is a multi-disciplinary open access archive for the deposit and dissemination of scientific research documents, whether they are published or not. The documents may come from teaching and research institutions in France or abroad, or from public or private research centers.
L'archive ouverte pluridisciplinaire HAL, est destinée au dépôt et à la diffusion de documents scientifiques de niveau recherche, publiés ou non, émanant des établissements d'enseignement et de recherche français ou étrangers, des laboratoires publics ou privés. 


\title{
Copper stress proteomics highlights local adaptation of two strains of the model brown alga Ectocarpus siliculosus*
}

\author{
Andrés Ritter 1,2,3, Martin Ubertini ${ }^{1,2}$, Sarah Romac ${ }^{4}$, Fanny Gaillard ${ }^{4}$, Ludovic Delage ${ }^{1,2}$, \\ Aaron Mann ${ }^{3}$, J. Mark Cock ${ }^{1,2}$, Thierry Tonon ${ }^{1,2}$, Juan A. Correa ${ }^{3}$ and Philippe Potin ${ }^{1,2}$ \\ ${ }^{1}$ Université Pierre et Marie Curie-Paris 6, Végétaux Marins et Biomolécules, Station Biologique, Place Georges \\ Teissier, Roscoff, France \\ ${ }^{2}$ CNRS, Végétaux Marins et Biomolécules, Station Biologique, Place Georges Teissier, Roscoff, France \\ ${ }^{3}$ Departamento de Ecología, Center for Advanced Studies in Ecology \& Biodiversity, Facultad de Ciencias \\ Biológicas, Pontificia Universidad Católica de Chile, Santiago, Chile \\ ${ }^{4}$ Computer and Genomics resource Centre, Station Biologique, Place Georges Teissier, Roscoff, France
}

Ectocarpus siliculosus is a cosmopolitan brown alga with capacity to thrive in copper enriched environments. Analysis of copper toxicity was conducted in two strains of E. siliculosus isolated from (i) an uncontaminated coast in southern Peru (Es32) and (ii) a copper polluted rocky beach in northern Chile (Es524). Es32 was more sensitive than Es524, with toxicity detected at 50 $\mathrm{g} / \mathrm{L}$ $\mathrm{Cu}$, whereas Es524 displayed negative effects only when exposed to $250 \mu \mathrm{g} / \mathrm{L} \mathrm{Cu}$. Differential soluble proteome profiling for each strain exposed to sub-lethal copper levels allowed to identify the induction of proteins related to processes such as energy production, glutathione metabolism as well as accumulation of HSPs. In addition, the inter-strain comparison of stress-related proteomes led to identify features related to copper tolerance in Es524, such as striking expression of a PSII Mn-stabilizing protein and a Fucoxanthine chlorophyll a-c binding protein. Es524 also expressed specific stress-related enzymes such as RNA helicases from the DEAD box families and a vanadium-dependent bromoperoxidase. These observations were supported by RT-qPCR for some of the identified genes and an enzyme activity assay for vanadium-dependent bromoperoxidase. Therefore, the occurrence of two different phenotypes within two distinct E. siliculosus strains studied at the physiological and proteomic levels strongly suggest that persistent copper stress may represent a selective force leading to the development of strains genetically adapted to copper contaminated sites.

\section{Keywords:}

2-DE / Algae / Bromoperoxidase / Copper / Plant proteomics / Stress
Received: January 3, 2009

Revised: October 28, 2009 Accepted: November 19, 2009

\section{Introduction}

The release of heavy metals, including copper, by a wide range of human activities, remains a major threat for

Correspondence: Dr. Philippe Potin, UPMC-Paris 6, CNRS, UMR 7139 Végétaux Marins et Biomolécules, Station Biologique, Place Georges Teissier, BP74, F 29682, Roscoff, France

E-mail: potin@sb-roscoff.fr

Fax: $+33-2-98292324$

Abbreviations: $\boldsymbol{F}_{\mathrm{v}} / \boldsymbol{F}_{\mathrm{m}}$, maximum quantum yield of PSII (dark adapted); GSH, glutathione; LHC, light harvesting complex; OEC, oxygen evolving complex; PC, phytochelatin; PMF, protein mass fingerprint; SAM, S-adenosyl methionine; SHMT, serine hydroxymethyl transferase; vBPO, vanadium dependent bromoperoxidase marine ecosystems, impacting benthic flora and fauna assemblages [2-4]. Copper is a micronutrient essential for all forms of life, acting as cofactor for many enzymatic systems and participating in crucial physiological processes including photosynthesis and respiration. However, copper is extremely toxic at high concentrations, particularly affecting photosynthetic organisms that suffer effects on chlorophyll structure, synthesis and function, on fatty acid metabolism, and on carbohydrate synthesis [5-7]. In addition, copper can catalyze the synthesis of the highly reactive hydroxyl radical in presence of $\mathrm{H}_{2} \mathrm{O}_{2}$ via

\footnotetext{
*Publication of this paper was delayed after final acceptance due to awaiting publication of the Ectocarpus genome paper by Cock et al. [1] and the public release of the genome data.
} 
the Fenton reaction, a process that causes oxidative stress $[8,9]$.

Some local geographic areas that have been chronic recipients of wastes containing heavy metals (i.e. mine wastes) constitute a persistent stressful environment that acts as a selective force leading, in some cases, to the generation of tolerant strains genetically adapted [10-13]. In northern Chile, copper mine wastes discharges were, for almost 70 years, a major and only source of coastal pollution at Chañaral bay and surroundings, where local disturbances included the creation of large tailing beaches and the disappearance of most of the seaweeds and invertebrates $[2,14]$. The process of biological recovery, expected to follow after tighter legislation, is far from being complete and many key ecological species, such as the brown kelp Lessonia nigrescens [14], are still absent. Among the few species recorded in this area, the filamentous brown alga Ectocarpus siliculosus is a persistent inhabitant, thriving in tide pools [14]. Early studies on E. siliculosus have identified copper tolerant populations, isolated from the hulls of ships treated with copper-based antifouling paints [15-18]. Although copper exclusion mechanisms were proposed for explaining this differential tolerance, analytical methods did not allow identifying genetically distinct population traits and/or characterizing the physiological or molecular bases leading to this differential tolerance. Nowadays, major advances have been made in vascular plants toward understanding copper homeostasis and tolerance [19-21]. Vascular plants have evolved a number of general detoxification mechanisms, the best known being complexation by strong ligands such as phytochelatins (PCs) and metallothioneins [22]. Other plant chelating mechanisms employ organic acids such as histidine, proline or nicotianamine [20, 21, 23]. Active metal exclusion mediated by P-type ATPases may also act for detoxification of copper in Arabidopsis [24]. Compared to the large body of literature available for vascular plants, much less is known about the mechanisms responsible for copper detoxification in brown algae. In the genus Fucus, metallothioneins and PCs were induced by copper excess $[25,26]$. Phenolic compounds have been proposed as metal chelators, but results seem contradictory among species [27-30]. In addition, charged sulfated polysaccharides of the cell wall could play an important role acting as primary ion filter of algal cells [28, 31]. Once inside the cell, it is well documented that metals in general, and copper in particular, activate antioxidant mechanisms in seaweeds [32, 33]. Moreover, $\mathrm{Cu}$-induced ROS production in brown algae seems to trigger oxylipin signaling pathways that could be related to detoxification mechanisms [34]. Brown algae (class Phaeophyceae) belong to the division Heterokonta, which evolved as an independent lineage more than a billion years ago [35]. Based on their particular evolutionary history, it is likely that original physiological mechanisms have evolved in these organisms in order to adapt to the various and highly fluctuating habitats they colonize. Consistent with this, a recent study underlined a unique antioxidant system based on iodide metabolism in the kelp Laminaria digitata [36]. Because of the particular evolutionary history of the Division, a consortium of laboratories initiated a project in 2004 to sequence the genome of E. siliculosus. At present, the annotation has been achieved, and this will allow large-scale genome explorations [1] The pertinence of using E. siliculosus as a facultative metallophyte, its easy handling in the laboratory and the current efforts to develop this species as a model organism for Phaeophyceae [37] make it an attractive candidate for studying metal tolerance through global approaches such as proteomics.

At the proteomic level, whereas several studies on plant responses to heavy metal stress exist, they are mostly restricted to the exposure to arsenic, cadmium, and zinc [38, 39]. Fewer reports on this domain concern copper stress. Some proteomic studies have focused on the glutathione-S-transferase family regulation caused by copper excess [40], and the copper-binding proteins of Arabidopsis roots and seedlings have been explored by IMAC-MS [41]. Recently, the molecular effects of copper on the root proteome of Cannabis sativa was investigated by 2-DE-based analysis [42]. At the present time, no meaningful proteomic study does exist in marine algae. This is probably due to the fact that until recently no adequate techniques for obtaining high-quality protein extracts was available for these organisms [43]. In this work, copper tolerance of two E. siliculosus strains, originating from habitats with contrasting histories of copper levels, was analyzed by a comparative 2-DE proteomic approach. Patterns of differentially expressed proteins were compared within and between the two strains to better identify several cellular processes potentially involved in copper stress responses and tolerance.

\section{Materials and methods}

\subsection{Plant material and cultivation treatments}

E. siliculosus (Ectocarpales, Phaeophyceae) unialgal strains 32 (Culture Collection of Algae and Protozoa accession $1310 / 4$, origin San Juan de Marcona, Peru $15^{\circ} 22^{\prime} \mathrm{S}$, $75^{\circ} 10^{\prime} \mathrm{W}$ ) and 524 (Culture Collection of Algae and Protozoa accession 1310/333, origin Caleta Palito, Chile $26^{\circ} 15^{\prime} \mathrm{S}$, $\left.70^{\circ} 40^{\prime} \mathrm{W}\right)$ were cultivated in 10 -L plastic flasks in a culture room at $14^{\circ} \mathrm{C}$ using $0.22 \mu \mathrm{m}$ filtered seawater enriched with Provasoli nutrients [44]. Light was provided by Philips daylight fluorescence tubes at a photon flux density of $40 \mu \mathrm{mol}$ photon $/ \mathrm{m}^{2} / \mathrm{s}$ for $14 \mathrm{~h}$ per day. Cultures were aerated with filtered $(0.22 \mu \mathrm{m})$ compressed air to avoid $\mathrm{CO}_{2}$ depletion.

Two days before exposing the algae to copper excess, tissues were transferred into $1 \mathrm{~L}$ of seawater free of organic matter prepared with $0.22 \mu \mathrm{m}$ filtered natural SW treated overnight with $0.2 \mathrm{~g} / \mathrm{L}$ activated charcoal (Merck, Germany). Treated water was then filtered at $0.45 \mu \mathrm{m}$ to remove charcoal 
excess. Culture flasks used during the experiments were washed overnight with $1 \% \mathrm{HCl}$ to limit copper adsorption to glass. Copper stress was triggered by changing the algae to fresh seawater free of organic matter and enriched with $\mathrm{CuCl}_{2}$ (Merck, Germany) at nominal final concentrations of 50, 150, 250 and $500 \mu \mathrm{g} / \mathrm{L}$. The term "acute stress" was employed for conditions of exposure to high copper concentrations $(250-500 \mu \mathrm{g} / \mathrm{L})$ during short periods of time (4-8h). On the other hand, "chronic stress" defines the exposure to lower sub-lethal copper concentrations $(50-150 \mu \mathrm{g} / \mathrm{L})$ during longer periods of time (6-10 days). No nutrients were added during the experiments. Culture media were renewed every 2 days. For each kinetic point, three replicate algal samples were harvested. At the end of the experiment, thalli were frozen in liquid nitrogen and kept at $-80^{\circ} \mathrm{C}$ for analysis.

\subsection{In vivo fluorescence measurements and microscopic observations}

To monitor the intensity of the stress in the algal tissues caused by the copper treatments we measured the maximum quantum yield of PSII (dark adapted) as $F_{\mathrm{v}} / F_{\mathrm{m}}$, using a Walz Phyto-PAM (Waltz, Germany). After 5 min of dark adaptation, samples were illuminated with modulated excitation light, provided by a combination of photodiodes emitting at 470 , 520,645 and $665 \mathrm{~nm}$, at a frequency of $25 \mathrm{~Hz}$, in order to define the basal fluorescence level $F_{0}$. After signal stabilization, a light pulse was triggered by a red light emitting photodiode array $\left(3500 \mu \mathrm{mol}\right.$ photon $/ \mathrm{m}^{2} / \mathrm{s}$ intensity for $200 \mathrm{~ms}, 655 \mathrm{~nm})$, which allowed measuring maximal fluorescence level $F_{\mathrm{m}}$. The emitted fluorescence is detected at a wavelength range above $710 \mathrm{~nm}$. The PSII quantum yield was then calculated as $F_{\mathrm{v}} / F_{\mathrm{m}}=\left(F_{\mathrm{m}}-F_{0}\right) / F_{\mathrm{m}}$. Since photosynthesis is stress sensitive, the quantum yield decreased under suboptimal (stressful) conditions. Simultaneously to PAM measurements, loss of chlorophyll autofluorescence, accounting for cell damage, was monitored using an Olympus BX60 (Olympus, Japan) epifluorescence microscope. Thalli were observed with a 460-500 $\mathrm{nm}$ excitation filter and a band pass emission filter centered at $585 \mathrm{~nm}$. Images were obtained using a digital camera (DIAGNOSTIC instruments model 2.1.1). The number of fluorescent cells was estimated and represented as percentage of fluorescent cells.

\subsection{Protein extraction and 2-DE separation}

Global soluble proteome extraction followed the protocol developed by Contreras et al. [43]. A total of $300 \mathrm{mg}$ of tissue (fresh weight) was rinsed with Milli-Q water, blotted dry and fast frozen in liquid nitrogen. After tissue grinding in liquid nitrogen, powder was re-suspended in $5 \mathrm{~mL}$ of extraction buffer $(1.5 \% \mathrm{w} / \mathrm{v}$ PVP, $0.7 \mathrm{M}$ sucrose, $0.1 \mathrm{M} \mathrm{KCl}, 0.5 \mathrm{M}$ Tris$\mathrm{HCl}, \mathrm{pH} 7.5,250 \mathrm{mM}$ EDTA, complete protease inhibitor cocktail (Roche, Switzerland), 2\% v/v $\beta$-mercaptoethanol and $0.5 \% \mathrm{w} / \mathrm{v}$ CHAPS) and homogenized at $4{ }^{\circ} \mathrm{C}$ for $20 \mathrm{~min}$. Then, $10 \mathrm{~mL}$ of Tris- $\mathrm{HCl} \mathrm{pH} 7.5$ saturated phenol was added and the mixture was re-homogenized for $20 \mathrm{~min}$ at $4{ }^{\circ} \mathrm{C}$. The mixture was centrifuged at $10000 \times \mathrm{g}$ for $20 \mathrm{~min}$ and the upper phenol phase was removed. Proteins in the phenol phase were precipitated by addition of five volumes of $0.1 \mathrm{M}$ ammonium acetate dissolved in methanol and incubated at $-20^{\circ} \mathrm{C}$ for $3 \mathrm{~h}$. The extract was centrifuged at $10000 \times \mathrm{g}$ for $20 \mathrm{~min}$, the supernatant was discarded and the protein pellet was rinsed in ammonium acetate $(0.1 \mathrm{M}$ in methanol) for $20 \mathrm{~min}$ at $-20^{\circ} \mathrm{C}$. Subsequently, the protein pellet was rinsed four times in four volumes of $80 \%$ ice-cold acetone. The pellet was then re-suspended in 2-DE compatible buffer (7 M Urea, $2 \mathrm{M}$ Thiourea, 4\% w/v CHAPS, $60 \mathrm{mM}$ DTT, $20 \mathrm{mM}$ Tris- $\mathrm{HCl}, \mathrm{pH} 8.8$, and $1 \times$ Biolytes, $\mathrm{pH} 3-10$, from BioRad, USA). A final cleaning step was incorporated using the 2-D Clean-up Kit (BioRad). The extracts were stored at $-80^{\circ} \mathrm{C}$. The total protein concentration was assayed by using the 2-D quant kit (GE Healthcare, USA). For each replicate, $500 \mu \mathrm{g}$ of total protein extract was loaded into a 17$\mathrm{cm}$ non-linear ReadyStrip pH range 4-7 (BioRad). The 2-DE proteome separation and gel staining was carried out as described elsewhere [43]. Further information about the gel electrophoresis procedure is available at the MIAPE-GE table : http://www.sb-roscoff.fr/UMR7139/ectocarpus/ proteomics/001/MIAPE/MIAPEGE sheet.htm.

\subsection{Image analysis}

Gel images obtained using an Image scanner UMAX Powerlook III (UMAX Technologies, USA) at 300 dpi resolution were analyzed with the Melanie version 5.0 software (Swiss Institute of Bioinformatics, Switzerland). Manual editing and normalization were applied after automated spot detection and matching. Spot quantification was based on spot volume (integration of spot density over spot area) as percentage of the total spot volumes of the gel to normalize for possible staining differences between gels. Gel annotations and matching fidelity were checked manually to eliminate matching errors caused by the software. Three gels representing independent biological samples were analyzed for each condition. All spots selected for MS analyses presented statistically significant variation $(p<0.05)$, ratio $<1.5$ and an average fold change $<2$ (at least in one of the stressed conditions). Further information regarding gel analyses is available at the MIAPE-GI information sheet:

http://www.sb-roscoff.fr/UMR7139/ectocarpus/proteomics/ 001/MIAPE/MIAPE GI sheet.htm.

\subsection{Protein mass fingerprints (PMF)}

Coomassie blue-stained protein-bearing gel slices were cut into small pieces, washed with distilled water and de-stained with ACN. The cysteine residues were reduced by $100 \mu \mathrm{L}$ of 
$10 \mathrm{mM}$ DTT at $56^{\circ} \mathrm{C}$ and alkylated by $150 \mu \mathrm{L}$ of $55 \mathrm{mM}$ iodoacetamide at room temperature. The iodoacetamide solution was replaced by $100 \mu \mathrm{L}$ of $100 \mathrm{mM} \mathrm{NH}_{4} \mathrm{HCO}_{3}$ and gel dehydration was achieved with ACN. After evaporation in Speed-Vac (Thermo, USA), proteins were digested overnight at $37^{\circ} \mathrm{C}$ in a solution containing $0.9 \mu \mathrm{g}$ of a modified sequencing grade bovine trypsin (Roche, Germany) prepared in $25 \mathrm{mM} \mathrm{NH} \mathrm{mHCO}_{3}$. Finally, a double extraction followed, first with $5 \% \mathrm{v} / \mathrm{v}$ formic acid and subsequently with $100 \% \mathrm{v} / \mathrm{v}$ ACN. The resulting peptide mixture was extracted and vacuum-dried, re-suspended in $1 \%$ formic acid and desalted using a ZipTip (Millipore, USA) C-18 reverse phase microcolumn. After evaporation, the desalted peptide mixture was re-suspended in $10 \mu \mathrm{L}$ of $1 \%$ formic acid. PMF by MALDI-TOF-MS was performed using a Voyager DESTR MALDI-TOF mass spectrometer (Applied Biosystems, USA). One microliter of tryptic digest was mixed with an equal volume of CHCA matrix (Sigma; $10 \mathrm{mg} / \mathrm{L}$ in $50 \%$ ACN, $0.1 \%$ TFA) and spotted onto the MALDI target. Spectra were acquired in positive ion reflector mode under $20 \mathrm{kV}$ accelerating voltage and a mass range of 800-4000 Da. Internal calibration was performed using trypsin autolysis fragments at $m / z 1433.70,2163.05$ and 2289.1. The monoisotopic masses of tryptic peptides were used to query the specific E. siliculosus protein database deduced from the version 2 of the genome annotation (genome accessible at http://bioinformatics.psb.ugent.be/webtools/bogas) using Mascot version 2.1. Search conditions included an initially permissive mass window of $200 \mathrm{ppm}$ for external calibration, followed by 100-50 ppm applied for internal calibration with trypsin autodigestion fragments (when trypsin peptides were detected), allowing double missing cleavage, modification of cysteines by iodoacetamide, methionine oxidation and $N$-terminal pyroglutamylation as variable modifications. Only significant scores were selected for publication. Further information regarding the MS procedures is accessible at the MIAPE-MS information sheet:

http://www.sb-roscoff.fr/UMR7139/ectocarpus/proteomics/ 001/MIAPE/MIAPE MS sheet.htm.

\subsection{RNA extraction and RT-qPCR analysis}

The RNA extraction, quantification, cDNA synthesis and RT-qPCR reactions followed the protocol described by Le Bail et al. [45]. For each gene, a specific pair of oligonucleotide primers in the $3^{\prime}$ coding sequence (Supporting Information Table S1) was designed using Beacon designer 5.00 (Premier Biosoft International, USA). The qPCR reactions were done in a Chromo4 apparatus (Biorad) with a SYBR Green reaction mix AB-1162/B from ABgene (UK). A dilution series ranging from 91 to 121312 copies of the E. siliculosus genome was prepared. The Dynein gene was used as internal control as previously described [45]. Relative variations in gene expression were calculated as $x$-fold changes compared with the appropriate control treatment.

\subsection{Bromoperoxidase activity assay}

Total protein extracts were obtained from of $0.2-0.5 \mathrm{~g}$ of fresh weight tissue, grounded in liquid nitrogen and mixed with $0.4 \mathrm{~mL}$ of extraction buffer containing $25 \mathrm{mM}$ MOPS, pH 7.2, $15 \mathrm{mM} \mathrm{MgCl}$, 15 mM EGTA, 1 mM DTT, 0.5\% PVP and anti-proteases cocktail at a concentration specified by the manufacturer (Roche, France). Extracts were homogenized for $1 \mathrm{~h}$ at $4{ }^{\circ} \mathrm{C}$, centrifuged at $10000 \times \mathrm{g}$ for $30 \mathrm{~min}$ and the supernatant collected. Vanadate was added to the extracts at $1 \mathrm{mM}$ final concentration, after which they were incubated at $4^{\circ} \mathrm{C}$ for at least $1 \mathrm{~h}$ prior to the analysis. The total amount of proteins was quantified using the Bradford assay [46], and $20 \mu \mathrm{g}$ were loaded on the gel. Bromoperoxidase enzymatic assay was conducted on non-denaturing gels as described elsewhere [47]. The activity levels using band density in the gels were assessed by the ImageQuant v5.2 software (Molecular Dynamics, GE Healthcare, USA). The relative changes among conditions were calculated as Volume Intensity and quantified in arbitrary units (AU).

\subsection{Statistical analysis}

The statistical significances of the differences among treatments were determined by the non-parametric Mann-Whitney $U$ test run on Statistica version 5.1 software (StatSoft, USA). All conclusions are based on at least $5 \%$ level of significance $(p<0.05)$.

\section{$3 \quad$ Results}

\subsection{Copper toxicity tests in strains Es32 and Es524}

The toxicity of copper was assessed in the two strains by in vivo measurements of chlorophyll fluorescence and by epifluorescence microscopy observations. The dose-response relationships between $\mathrm{Cu}$ concentrations and cell-mortality differed between both strains after 10 days of exposure to copper excess (Fig. 1A and B). In Es32, a significant drop to $70 \%$ of chlorophyll autofluorescence was observed under 10 days of incubation with $50 \mu \mathrm{g} / \mathrm{L} \mathrm{Cu}$, indicating the occurrence of cell death. On the other side, Es524 displayed a lower decay of cell-autofluorescence accounting for the deleterious effects only at $250 \mu \mathrm{g} / \mathrm{L} \mathrm{Cu}$ or higher. In agreement with these observations, the $F_{\mathrm{v}} / F_{\mathrm{m}}$ was negatively affected by $\mathrm{Cu}$ in both strains, but at different thresholds (Fig. 1C). After 10 days, a significant decline in the yield was observed in strain Es32 when copper concentration was higher than $50 \mu \mathrm{g} / \mathrm{L}$, with $F_{\mathrm{v}} / F_{\mathrm{m}}$ decreasing in a dose-dependent manner. After the same time of incubation, Es524 displayed significant decrease in $F_{\mathrm{v}} / F_{\mathrm{m}}$ only for $\mathrm{Cu}$ concentrations of $500 \mu \mathrm{g} / \mathrm{L}$. These results allowed to select the best concentrations to expose each isolate to non-lethal conditions of copper stress, treatments required for differential soluble proteome analyses. 
Es32
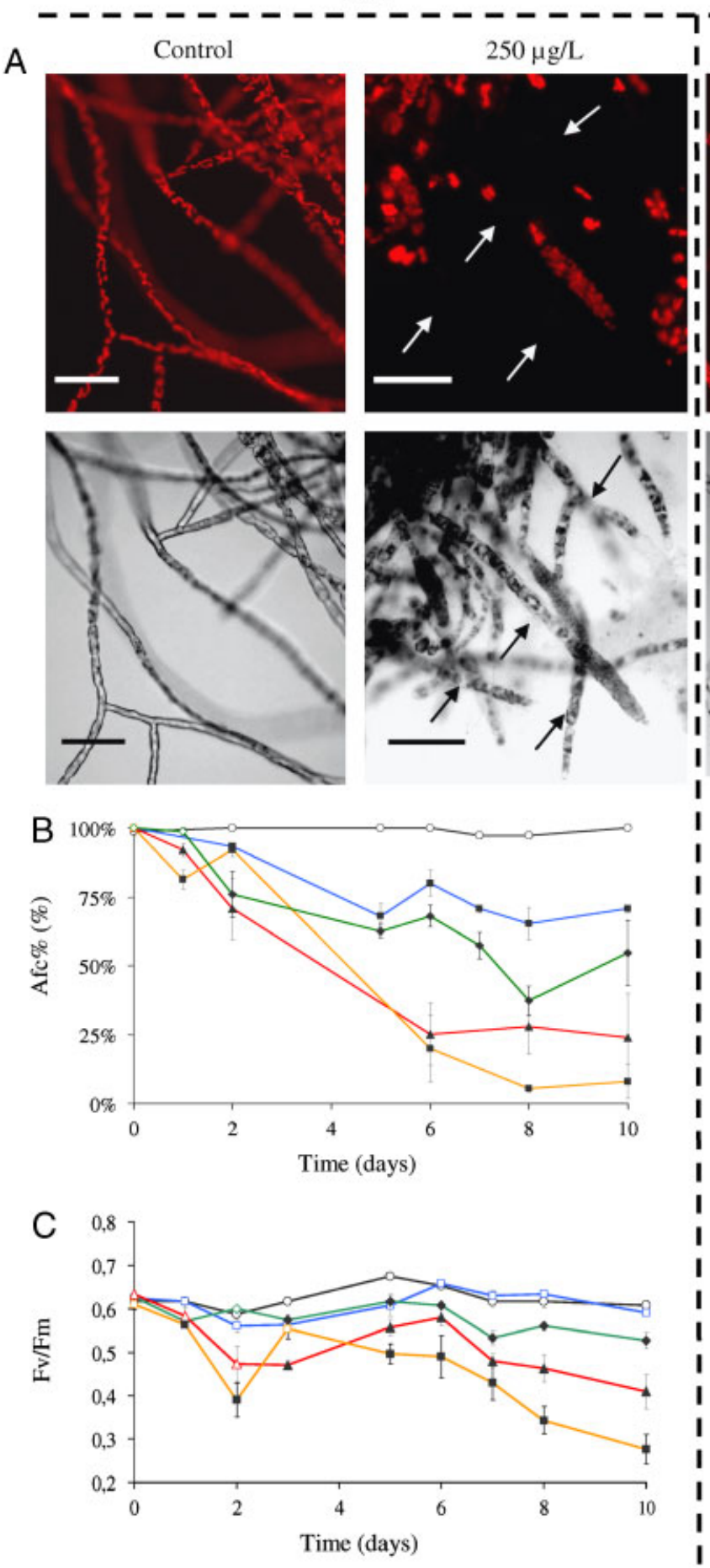

Es524
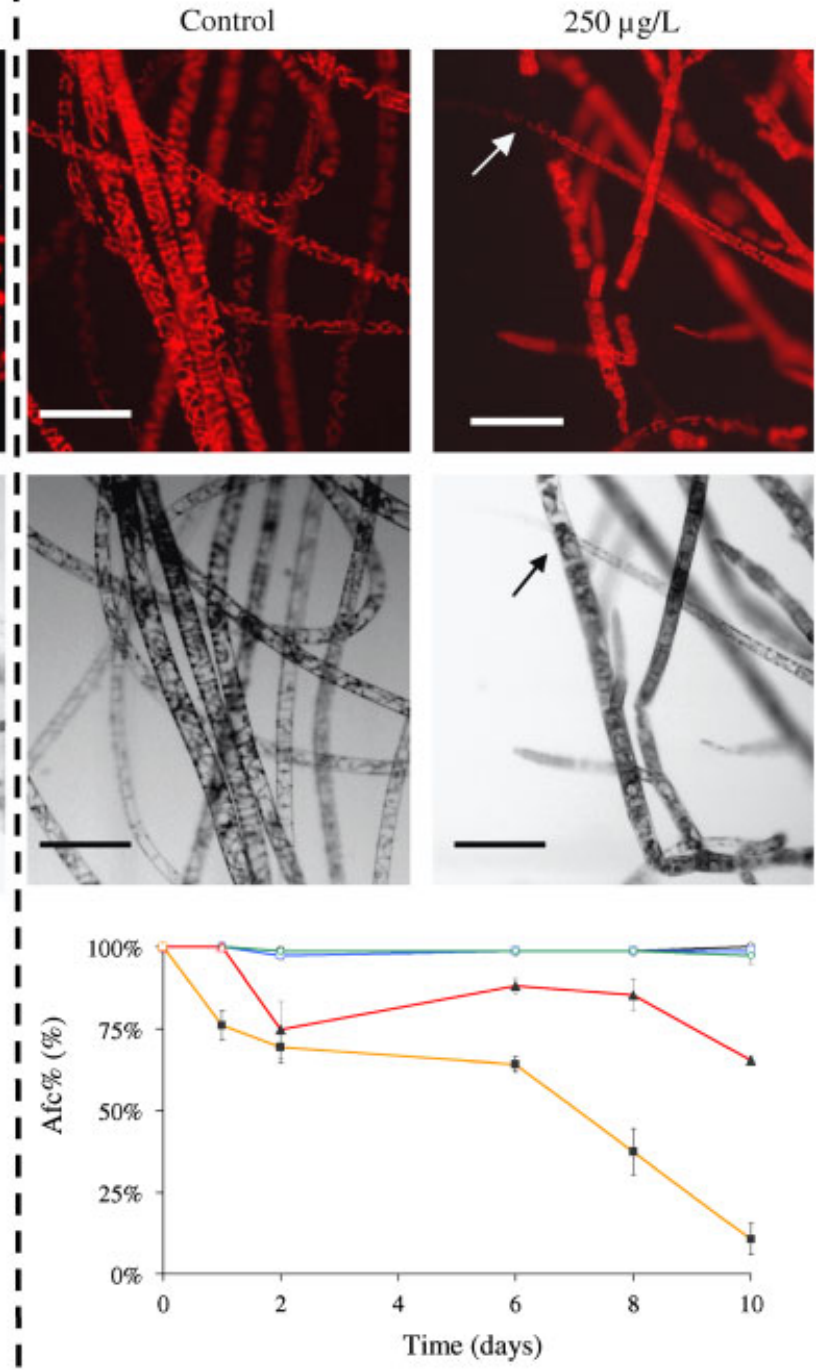

1
1
1
1
1
1
1

Figure 1. Physiological effects of copper toxicity on E. siliculosus strains Es32 and Es524. (A) Comparison of epifluorescence and transmission microscopic photographs after 10 days of copper treatment. Top images represent the green cut-off filter fluorescence images with their corresponding transmission images at the bottom. For each strain, the images are organized as follows: control condition (left) and $250 \mu \mathrm{g} / \mathrm{L}$ of copper (right). Bars represent $0.1 \mathrm{~mm}$. (B) Effect of different copper concentrations on the percentage of remaining auto-fluorescent cells during 10-day trials. Control seawater (black), and different concentrations of copper: $50 \mu \mathrm{g} / \mathrm{L}$ (blue), $150 \mu \mathrm{g} / \mathrm{L}$ (green), $250 \mu \mathrm{g} / \mathrm{L}$ (red) and $500 \mu \mathrm{g} / \mathrm{L}$ (orange). Values represent means of three independent replicates and bars represent the SE. Black-filled symbols represent a significantly different condition from the control group $(p<0.05)$. (C) Changes in the photosynthetic yield during 10-day trials. Control seawater (black), and different concentrations of copper: $50 \mu \mathrm{g} / \mathrm{L}$ (blue), $150 \mu \mathrm{g} / \mathrm{L}$ (green), $250 \mu \mathrm{g} / \mathrm{L}$ (red), $500 \mu \mathrm{g} / \mathrm{L}$ (orange). Values represent means of three independent replicates and bars represent the SE. Black-filled symbols represent a significantly different condition from the control group ( $p<0.05$ ). 


\subsection{Analyses of the proteins induced by chronic copper stress in Es32}

To identify proteins specifically regulated under chronic copper stress conditions, the most sensitive strain (Es32) was exposed to 10 days at $50 \mu \mathrm{g} / \mathrm{L}$ nominal $\mathrm{Cu}$. The 2-DE profiles of soluble proteome fractions were compared between control and treated thalli. Coomassie blue staining provided an average yield of 790 spots per gel (Supporting Information Fig. S1). Image analysis of the gels produced over 560 reproducible spot groups considering the two experimental conditions (Fig. 2A), with 58 statistically variable spots (ratio $>1.5$ ). Among these spots, two downregulated and eight upregulated proteins were selected for MS identification because they presented enough intensity to be located and excised manually (Fig. 2A). PMF spot identifications are described in Table 1. For most of the identified spots, the 2-DE observed molecular mass and $\mathrm{p} I$ values are in agreement with the theoretical values obtained from the corresponding protein hits in the genomic database. Among the identified enzymes, there was a transketolase belonging to the pentose phosphate metabolism. Several enzymes involved in amino acid metabolism were also identified. For instance, copper excess enhanced the accumulation of serine hydroxymethyl transferase (SHMT) and cysteine synthase involved in the biosynthesis of glycine and cysteine, respectively. Related to this, the nucleotide metabolism enzyme $S$-adenosyl methionine synthetase (SAM) also appeared increased. Protein folding was involved as well since a HSP10 and the HSP cochaperone Immunophilin FKBP 11 were more abundant in stressed individuals. Finally, the chaperone calreticulin was downregulated by copper excess.

\subsection{Analyses of the proteins induced by chronic copper stress in Es524}

The tolerant strain Es524 was exposed during 10 days to 50 and $150 \mu \mathrm{g} / \mathrm{L} \mathrm{Cu}$. Protein extracts from Es524 were analyzed with identical criteria as for Es32. The analysis of gel images obtained under the control condition and after treatment with $50 \mu \mathrm{g} / \mathrm{L}$ resulted in over 423 matched spot groups. Spot intensity analysis showed 32 differentially expressed spots (ratio $>1.5$ ). Among these spots, 20 were up-regulated and 12 down-regulated. On the other hand, comparison of control thalli with those exposed to $150 \mu \mathrm{g} / \mathrm{L}$ of copper produced 494 reproducible groups, from which 58 presented significant changes (Fig. 2B). For PMF, a first group of six spots corresponding to proteins accumulated under both treatments with copper excess was considered $(638,734,745,941,1174$ and 1176). Then, a second group was selected with nine spots only regulated by exposure to $150 \mu \mathrm{g} / \mathrm{L}$, corresponding to seven upregulated $(814,897,584,1089,768$ and 1184) and one downregulated (1252) proteins. PMF results are presented in Table 2. One enzyme involved in the pentose phosphate pathway, the G6PD, was identified. As for Es32, copper excess caused
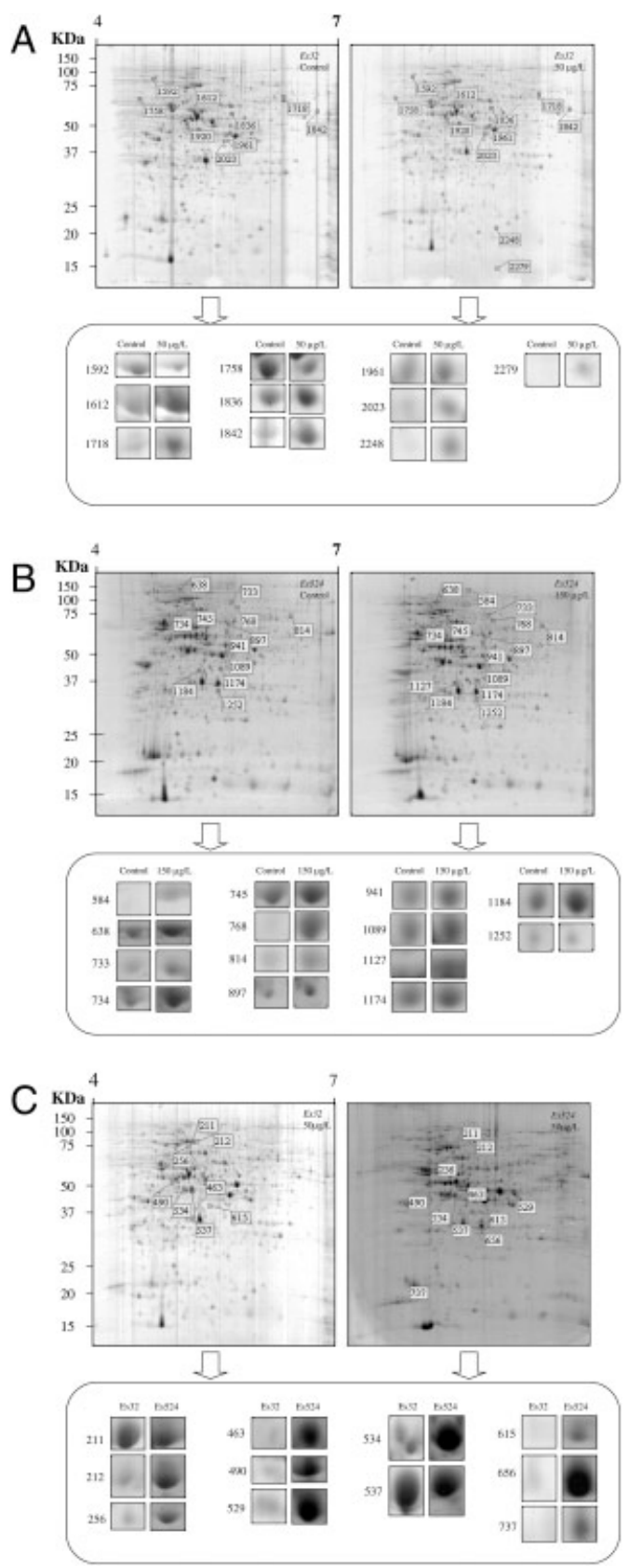

Figure 2. Proteomic profiling of E. siliculosus strains Es32 and Es524 in response to copper stress. (A) Representative 2-DE gels of total soluble proteome fractions of Es32 under control condition (left gel) and $50 \mu \mathrm{g} / \mathrm{L}$ of nominal $\mathrm{Cu}$, for 10 days (right gel) using a non-linear gradient of $\mathrm{p} / 4-7$. The identified differentially expressed spots are highlighted on the bottom panel. Spot identification numbers are listed on the left side of the images. (B) Representative 2-DE gels using a non-linear gradient of $\mathrm{p} / 4-7$ of total soluble proteome fractions of Es524 under control condition (left gel) and $150 \mu \mathrm{g} / \mathrm{L}$ nominal $\mathrm{Cu}$, for 10 days (right gel). Differentially expressed spots are highlighted on the bottom panel. (C) Representative 2-DE using a non-linear gradient of $\mathrm{p} / 4-7$ gels comparing total soluble proteomes between Es32 and Es524 submitted to $50 \mu \mathrm{g} / \mathrm{L}$ nominal $\mathrm{Cu}$ for 10 days. Differentially expressed proteins are highlighted on the bottom panel. 


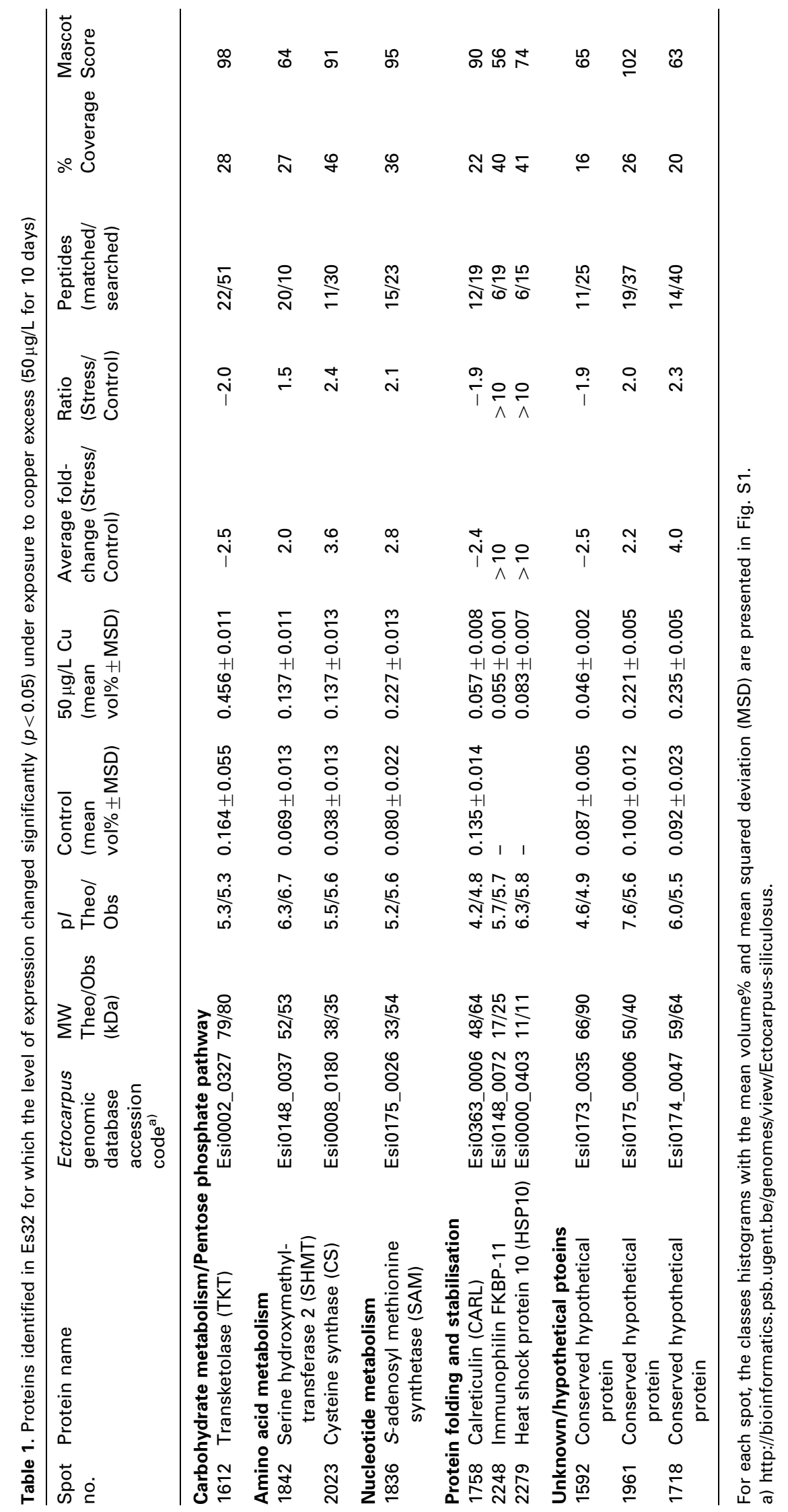




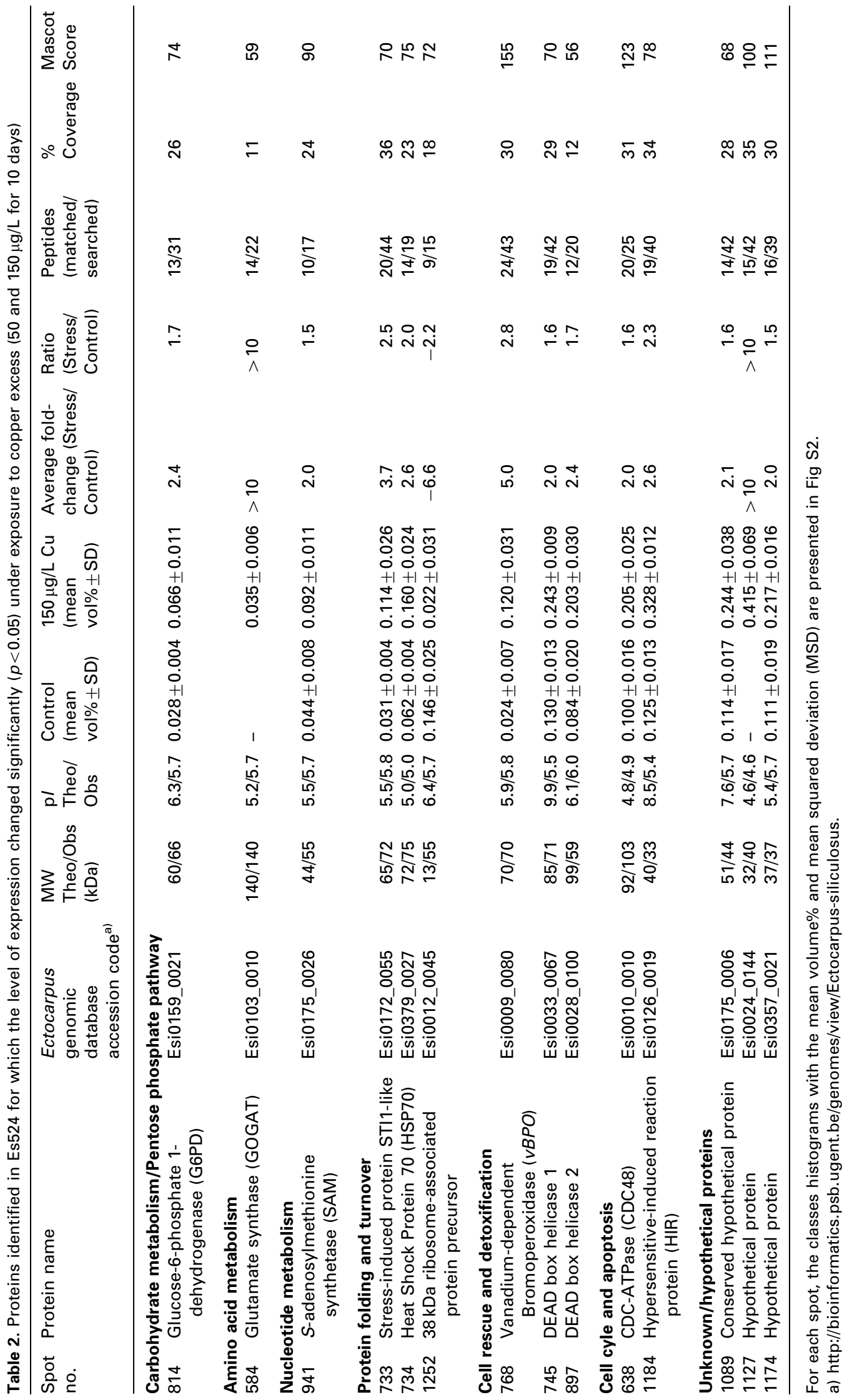




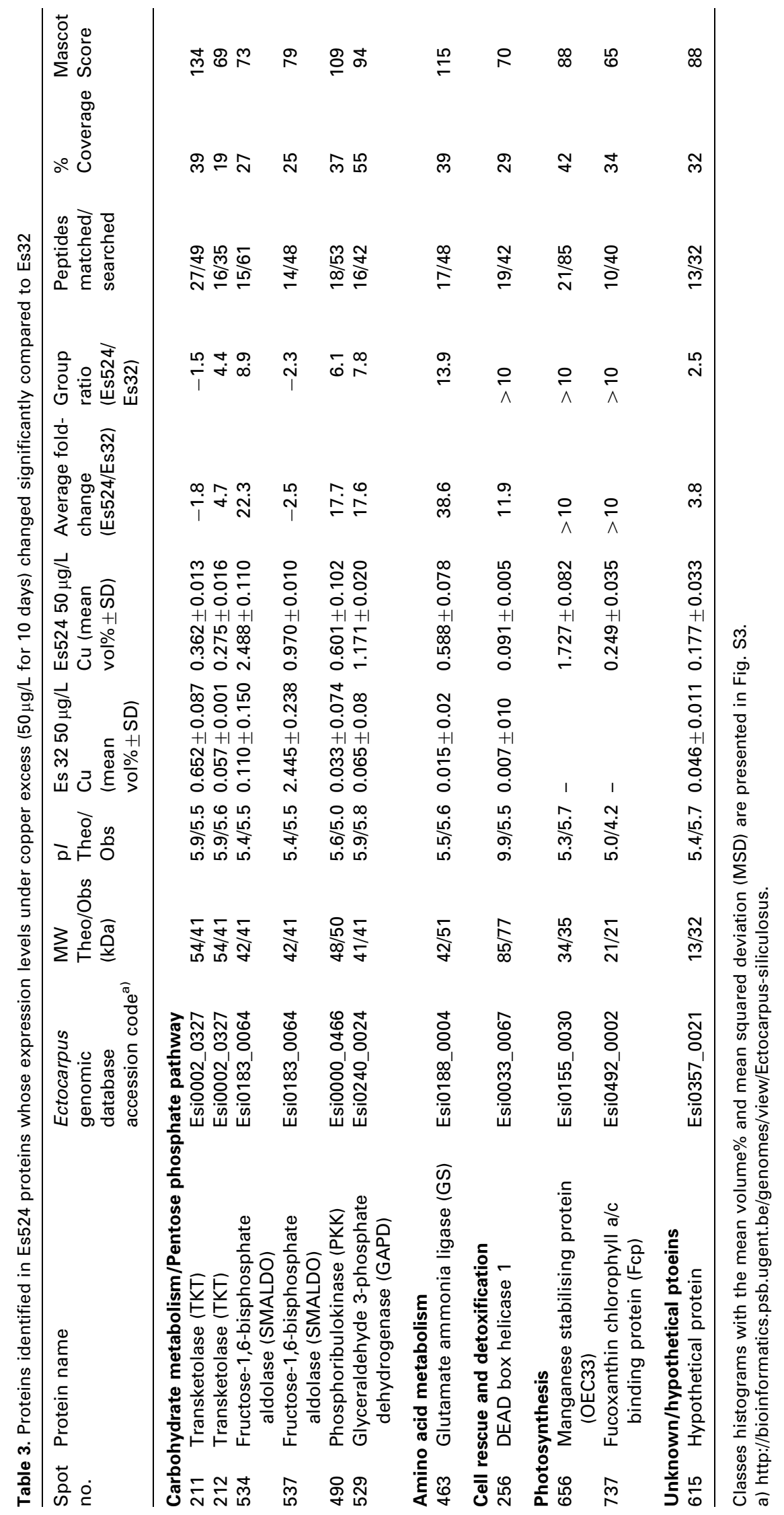


differential expression of enzymes involved in amino acid biosynthesis and nucleotide metabolism related enzymes, such as GOGAT and SAM. Copper excess clearly enhanced protein folding processes through the accumulation of the chaperone HSP70, and the HSP cochaperone stress-inducible protein (STI 1). Cell cycle may also be regulated by copper, as a hypersensitive-induced reaction protein and a CDC-ATPase accumulated under stress. Interestingly, among up-regulated spots in Es524, we found two RNA helicases from the DEAD box family, both related to the cell rescue process. In addition, one specific brown algal antioxidant-related enzyme, the vanadium-dependent bromoperoxidase (vBPO), was also identified in this set of proteins.

\subsection{Inter-strain differences in protein expression caused by copper excess}

Finally, patterns of proteome expression were compared between Es32 and Es524 exposed to $50 \mu \mathrm{g} / \mathrm{L}$ of copper after 10 days. Over 406 spots matched on reproducible groups between both strains, whereas 93 proteins were differentially expressed with a ratio higher than 2 (Fig. 2C). From these, in Es524 we identified nine clearly increased and two decreased spots, which were subsequently identified (PMF identification in Table 3). Two spots, corresponding to the same locus Esi0002_0327 and encoding for a potential pentose phosphate related transketolase, showed contrasting regulation in the two strains: increased in Es524 and decreased in Es32. Several other glycolysis and pentose phosphate metabolism-related enzymes were also markedly increased in Es524: a phosphoribulokinase, a glyceraldehyde-3-phosphate dehydrogenase and a fructose 1,6-bisphosphate aldolase (SMALDO). Concerning the amino acid metabolism, a GS appeared highly increased in Es524. Photosynthesis-related processes were also stimulated in this strain. For instance, the PSII Mn-stabilizing protein of the oxygen evolving complex (OEC33) was markedly overexpressed in Es524, while it was not detectable in Es32. Similar results were obtained for a light harvesting complex (LHC) protein Fucoxanthine chlorophyll a-c binding protein (Fcp).

\subsection{Expression analysis of selected key genes by RT- qPCR under acute and chronic stress conditions}

Four genes, encoding for proteins identified through proteomic analyses, $v B P O, H S P 70, H S P 10$ and SAM, were chosen for RT-qPCR experiments in order to compare changes in their level of expression during acute and chronic stress (Fig. 3A and B). Acute stress was induced by exposing algal cultures to 250 and $500 \mu \mathrm{g} / \mathrm{L}$ of copper for 4 and $8 \mathrm{~h}$. For chronic stress, final concentrations of 50 and $150 \mu \mathrm{g} / \mathrm{L}$ of $\mathrm{Cu}$ were applied for 6 and 10 days. Interestingly, $v B P O$ is the gene whose expression level was the most altered under stress. Its

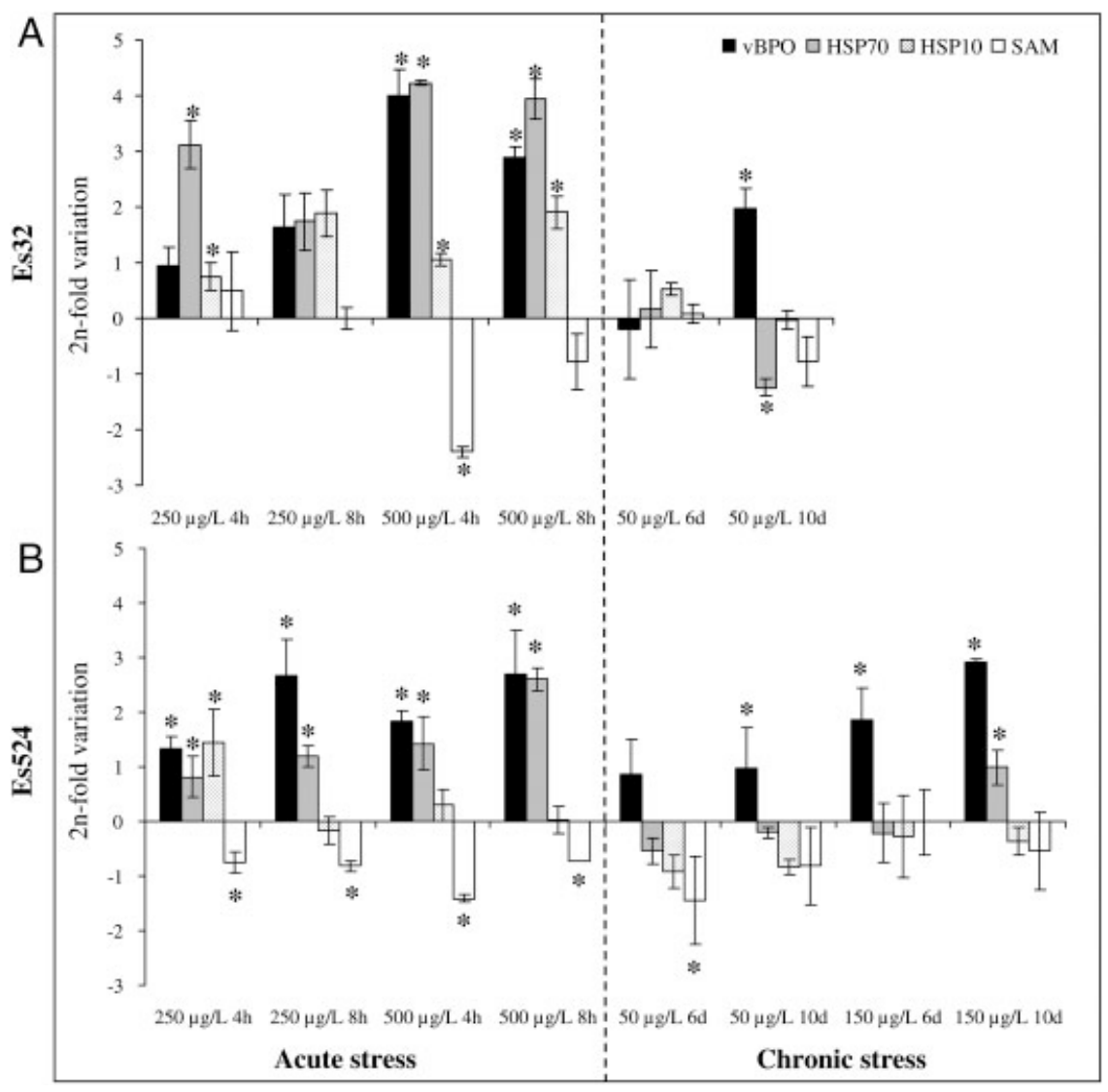

Figure 3. Changes in gene expression in E. siliculosus strains Es32 and Es524 exposed to acute and chronic stresses monitored by RT-qPCR. (A) Expression profile of vanadium bromoperoxidase ( $V B P O)$, heat shock protein 70 (HSP70), heat shock protein 10 (HSP10) and $S$-adenosyl methionine synthase ( $S A M)$ genes in Es32 submitted to acute $\mathrm{Cu}$ stresses (250 and $500 \mu \mathrm{g} / \mathrm{L}$ for 4 and $8 \mathrm{~h}$ ) at the left and chronic Cu stresses $(50 \mu \mathrm{g} / \mathrm{L}$ for 6 and 10 days) at the right. (B) Expression profile of $V B P O, H S P 70$, HSP10 and SAM genes from Es524 exposed to acute $\mathrm{Cu}$ stresses $(250 \mu \mathrm{g} / \mathrm{L}$ and $500 \mu \mathrm{g} / \mathrm{L}$ for 4 and $8 \mathrm{~h}$ ) at the left and chronic $\mathrm{Cu}$ stresses (50 and $150 \mu \mathrm{g} / \mathrm{L}$ for 6 and 10 days) at the right. Relative gene expression ratios were calculated as $2 \mathrm{n}$-fold variation as described in Section 2. Results are means \pm SE for two determinations from three independent biological samples. * Significantly different from the control group $(p<0.05)$. 
expression was induced under all the tested conditions in both strains, and more specifically, this gene was the most upregulated under chronic stress. Accumulation of HSP70 transcripts was observed under all acute stress conditions in Es32 (Fig. 3A) and Es524 (Fig. 3B). However, during chronic stress, the transcription of this gene was up-regulated only in Es524 exposed to $150 \mu \mathrm{g} / \mathrm{L}$ for 10 days. Significant changes in the expression of the HSP10 gene were recorded only under acute stress, mainly in Es32 (Fig. 3A). Slight induction of this gene was observed after incubation of Es524 for $4 \mathrm{~h}$ in presence of $250 \mu \mathrm{g} / \mathrm{L}$ copper. SAM gene was down-regulated in most of the conditions tested (Fig. 3A and B).

\subsection{Bromoperoxidase activity assay}

To assess the importance of $v B P O$ in the regulation of the oxidative stress created by $\mathrm{Cu}$ in Es32 and Es524, changes in enzymatic activity were followed on native PAGE gels. No visible activity was detected in Es32 under the control condition (Fig. 4A), while an intense band appeared under stress conditions, with an estimated molecular mass of $\sim 140 \mathrm{kDa}$. Quantification of the band intensity showed an increase of $4 \mathrm{E}+6 \mathrm{AU}$ in stressed Es32 (Fig. 4B). Protein extract from Es524 incubated in absence of copper showed only a slight coloration, indicating a low basal bromoperoxidase activity (Fig. 4C and D). After treatment with 50 or $150 \mu \mathrm{g} / \mathrm{L}$, a band similar to that observed in extracts from stressed Es32 was identified, demonstrating an increase in bromoperoxidase activity. The quantification of this band was estimated at $3 \mathrm{E}+6 \mathrm{AU}$ on all individuals and for both copper treatments. Similar results were obtained when replacing potassium bromide by potassium iodide during gel development, indicating that the protein identified in E. siliculosus exhibits a true $v B P O$ activity (data not shown).

\section{Discussion}

Studies of differential protein expression mapping are still uncommon in marine algal models. Proteomics allowed us to analyze responses to chronic stress in two strains in the marine brown alga E. siliculosus isolated from habitats contrasting in their history of copper enrichment. Exposure of these isolates to chronic conditions of copper stress allowed the identification of proteins and genes that help to support the hypothesis that isolate Es524 from Caleta Palito is a copper tolerant ecotype, which likely evolved after more than 60 years of exceedingly high levels of copper in its normal habitat. Protein accumulation analysis in both strains shows regulation of a high number of proteins directly implicated in various mechanisms of stress control, which validates the pertinence of this approach.

\subsection{Common protein expression features of the two isolates exposed to copper}

Surprisingly, the marked differences in tolerance to copper between the two isolates were not accompanied by major
A
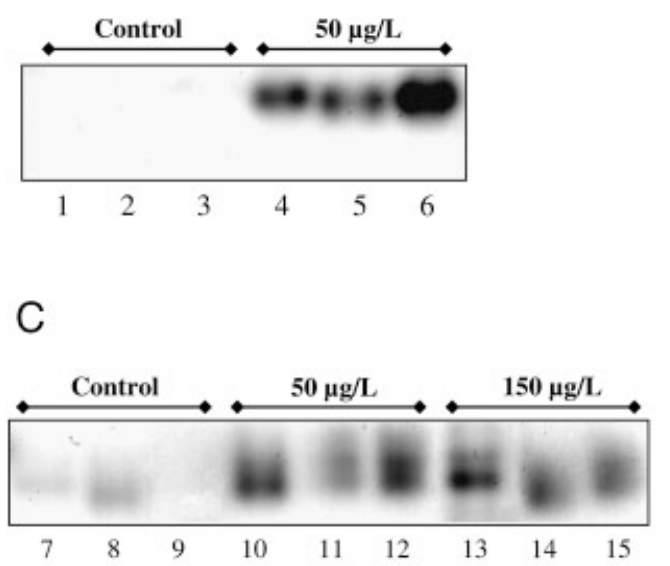
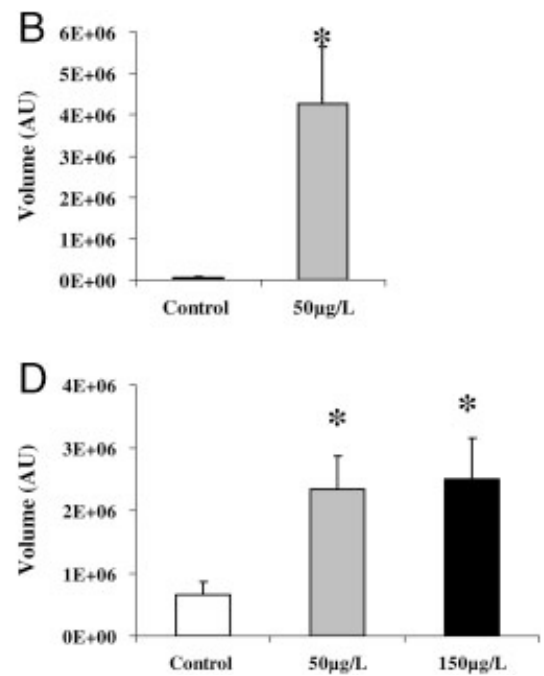

Figure 4. Native-PAGE bromoperoxidase (BPO) activity staining assay from E. siliculosus strains Es32 and Es524 exposed to 10 days of copper excess. Twenty microgram of each total protein extract were loaded into the gel for testing BPO activity as described in Section 2. (A) Lines 1-3: Es32 controls; lines 4-6: Es32 treated with $50 \mu \mathrm{g} / \mathrm{L}$ nominal copper. (B) Image band quantification of Es32 controls and $50 \mu \mathrm{g} / \mathrm{L} \mathrm{Cu}$ treated individuals. Values (arbitrary units, A.U.) represent the mean of the three replicates and SE. * Significantly different from the control group ( $p<0.05$ ). (C) Lines 7-9: Es524 controls; lines 10-12: Es524 treated with 50 $\mu \mathrm{g} / \mathrm{L}$ copper; lines 13-15: Es524 treated with $150 \mu \mathrm{g} / \mathrm{L}$ nominal copper. (D) Image band quantification of Es524 controls, 50 and $150 \mu \mathrm{g} / \mathrm{L}$ Cu-treated individuals. Values (arbitrary units, A.U.) represent the mean of the three replicates and SE. $*$ Significantly different from the control group ( $p<0.05$ ). 
differences in protein expression patterns. Exposure to sublethal copper concentrations induced the expression of proteins common to both strains, underlining the crucial importance of certain metabolic pathways during the response to stress. Copper induced the accumulation of proteins involved in pathways related to energy production such as the pentose phosphate pathway. These observations are in agreement with the correlation established between alteration of the photosynthesis and the ATP pool depletion in the diatom Phaeodactylum tricornutum [48]. Also, as in vascular plants [39], heavy metal stress induced the onset of repairing and detoxification systems, which represent an additional energetic cost for the cells, and therefore, the accumulation of enzymes involved in energy production in both isolates should not come as a surprise. In addition, the NADPH coming from the pentose phosphate shunt is one of the main cellular sources of reducing power, which is very important for detoxification, i.e. restoration of the reduced glutathione pool. In relation to this, copper stress activates enzymes involved in amino acid metabolism. These enzymes encompassed SHMT and cysteine synthase, linked to the biosynthesis of glycine and cysteine respectively. These two enzymes, plus the GOGAT/GS, are essential for the production of amino acid precursors used during the biosynthesis of glutathione $(\mathrm{GSH})$. In this context, GSH plays a pivotal role in protecting living organisms from environmental stresses $[49,50]$ by detoxifying ROS and toxins $[9,50,51]$. The GSH polymers PCs are fundamental for chelating metal excess in vascular plants [22]. Recently, concentrations of PCs and GSH in the brown algae Fucus vesiculosus and F. serratus have been correlated with the history of copper contamination of the sampling sites [25]. The enhanced GSH biosynthesis could also be related to the activity of the detoxification enzymes glutathione-S-transferases. Theses enzymes are particularly abundant in E. siliculosus, and some of them have been recently shown to be induced by copper stress (strain Es32) [52]. Theses findings, together with our results, highlight the involvement of thiol peptides in maintaining the homeostasis in brown algae under metal stress, as well as in detoxification processes. In addition, SAM, which synthesizes S-adenosyl methionine, was also up-regulated in both strains. Previous proteomic work in vascular plants and animals demonstrated that this enzyme was up-regulated under a condition of heavy metal stress $[38,53]$. This enzyme belongs to the methyl cycle that interacts with the GSH biosynthetic pathway, specifically at the level of the SHMT enzyme. In vascular plants, SAM is the direct precursor for nicotianamine, involved in copper complexation [54].

Both strains showed also up-regulation of enzymes involved in protein folding and stabilization, which are important players in recycling stress-damaged proteins. HSPs, known to be induced by a variety of stress conditions, and whose role is to protect cells against protein degradation $[55,56]$, appeared increased in both strains. Indeed, both strains up-regulated stress-related HSPs co-chaperones such as the stress-induced protein STI 1 and the Immunophilin-
FKBP 11. These co-chaperones are needed to create functionally active protein complexes by establishing interactions between HSPs [57]. Additional data obtained through gene expression analysis in Es32 showed a strong upregulation of HSP70 and HSP10 in response to acute copper stress. In contrast, level of expression of HSP10 was not regulated in Es524, which is in agreement with the proteomic results. In both strains, HSP 70 was mainly induced under acute exposures to copper excess, with a higher expression in Es32 than in Es524, suggesting an involvement in rapid stress responses rather than in adaptation.

The protein chaperone calreticulin was downregulated in Es32, whereas Es524 upregulates hypersensitive-induced reaction and CDC-ATPase proteins. These proteins participate in cell cycle control and apoptosis in several organisms, under a variety of stress, including metal ions [58-60]. Further studies should now be carried out to fully characterize the stress responses of Ectocarpus.

\subsection{Strain-specific responses}

Several individual proteins exhibited inter-strain qualitative or quantitative differences in expression. An increased expression of the LHC component Fcp was observed in Es524. In brown algae, and as in other photosynthetic organisms, LHC is primarily damaged by a wide range of abiotic stresses $[20,61,62]$. Therefore, the enhanced turnover of Fcp could contribute to the maintenance of the LHC integrity in this strain. Copper excess can also damage directly the PSII, generating oxidative stress as a result of the PSII dysfunction [6, 9, 63-65]. In agreement with this, a marked increase in OEC33 was observed in Es524 when compared with Es32. This could account for an enhanced turnover of OEC33, which constitutes a major copper toxicity target in PSII $[64,66]$. From these observations, it seems that differences in the expression of proteins related with the photosynthetic apparatus can explain, at least partly, the different response to $\mathrm{Cu}$ stress displayed by the two strains used in this study. However, further research is necessary to fully address the issue of differential copper tolerance.

The enzymes involved in cell detoxification, DEAD box helicases and $v B P O$, appeared increased under copper stress in Es524 but not in Es32. RNA helicases from the DEAD box family are found in almost all organisms and have important roles in RNA metabolism [67]. Moreover, these enzymes have been reported to play important roles in resistance to abiotic stress in vascular plants [68, 69]. Two DEAD box helicases accumulated in copper-stressed Es524, which suggests their involvement in copper tolerance. On the other hand, vBPOs are peroxidases unique to brown and red algae, and are absent in vascular plants or metazoans [70]. They catalyze the oxidation of bromide, as well as iodide, in the presence of hydrogen peroxide, to generate oxidized halogens which are thought to be related to iodine uptake [71]. Recent studies in the kelp L. digitata showed 
that iodine was mainly stored in the apoplastic region as iodide [36, 72]. Küpper et al. presented iodide as a powerful scavenger for a wide variety of ROS because of its high reducing capacity [36]. Furthermore, these authors suggested that $v B P O$ could catalyze this process. Gene expression analysis showed a strong induction of $v B P O$ in both strains under all conditions of copper excess, which highlights the importance of $v B P O$ in stress responses. In agreement with these results, the in-gel activity assay clearly showed the increase of $v B P O$ activity during chronic stress. Iodide metabolism is not well characterized in E. siliculosus and therefore this is, to our knowledge, the first study describing $\checkmark B P O$ and its regulation under stress in this species. Based on our results and on previous work in brown algae, it is likely that $v B P O$ s play a mayor role in the processes leading to ROS detoxification [36, 73]. In addition, if significant amounts of $\mathrm{I}^{-}$are released upon stress, it could be possible that complexation with $\mathrm{Cu}^{2+}$ occurs, leading to a nonbioavailable form of copper. However, additional research is required to test this hypothesis.

\subsection{Conclusions}

In this work, we have characterized two strains of E. siliculosus presenting different copper tolerance (Es32 and Es524). The availability of these different strains paves the way for future studies on the genetic bases of adaptative traits in seaweeds. Global proteome profiling led to identification of several pathways involved in copper tolerance and helped to better understand the differential tolerance to the metal observed between strains. In this context, photosynthesis-related proteins seem to be crucial for copper tolerance. In addition, we suggest the occurrence of an original antioxidant response of brown algae, based on halide metabolism and involving a vBPO.

This work has been partially funded by Marine Genomics Europe NoE 7 (EU contract no. GOCE-CT-2004-505403) and by the French Embassy and the CONICYT of Chile through PhD fellowships to A. R. This work was supported by the Laboratoire International Associe "Dispersal and Adaptation of Marine Species" (LIA DIAMS) PUC, Chile and CNRS-UPMC, France. Additional support came from FONDAP 1501-0001 (Program 7) and ICA research grant, both to J. A. C. We are especially grateful to Jessica Beltrán and Santiago Andrade for valuable suggestions.

These authors have declared no conflict of interest.

\section{References}

[1] Cock, J. M., Sterck, L., Rouzé, P., Scornet, D. et al., The Ectocarpus genome and the independent evolution of multicellularity in the brown algae. Nature 2010, in press, doi: $10.1038 /$ nature09016.
[2] Correa, J. A., Castilla, J., Ramirez, M., Varas, M. et al., Copper, copper mine tailings and their effect on the marine algae in Northern Chile. J. Appl. Phycol. 1999, 11, 57-67.

[3] Livingstone, D. R., Contaminant-stimulated reactive oxygen species production and oxidative damage in aquatic organisms. Mar. Pollut. Bull. 2001, 42, 656-666.

[4] Gledhill, M., Nimmo, M., Hill, S. J., Brown, M. T., The toxicity of copper (II) species to marine algae, with particular reference to macroalgae. J. Phycol. 1997, 33, 2-11.

[5] Maksymiec, W., Effect of copper on cellular processes in higher plants. Photosynthetica 1997, 34, 321-342.

[6] Yruela, I., Pueyo, J. J., Alonso, P. J., Picorel, R., Photoinhibition of photosystem II from higher plants. Effect of copper inhibition. J. Biol. Chem. 1996, 271, 27408-27415.

[7] Fernandes, J. C., Henriques, F. S., Biochemical, physiological, and structural effects of excess copper in plants. Bot. Rev. 1991, 57, 246-273.

[8] Halliwell, B., Gutteridge, J. M. C., Biologically relevant metal ion-dependent hydroxyl radical generation. An update. FEBS Lett. 1992, 307, 108-112.

[9] Halliwell, B., Reactive species and antioxidants. Redox biology is a fundamental theme of aerobic life. Plant Physiol. 2006, 141, 312-322.

[10] Baker, A. J. M., Proctor, J., The influence of cadmium, copper, lead, and zinc on the distribution and evolution of metallophytes in the British Isles. Plant Syst. Evol. 1990, 173, 91-108.

[11] Macnair, M. R., The genetics of metal tolerance in vascular plants. New Phytol. 1993, 124, 541-559.

[12] Pauwels, M., Roosens, N. H., Frérot, H., Saumitou-Laprade, P., When population genetics serves genomics: putting adaptation back in a spatial and historical context. Curr. Opin. Plant Biol. 2008, 11, 129-134.

[13] Medina, M. H., Correa, J. A., Barata, C., Micro-evolution due to pollution: possible consequences for ecosystem responses to toxic stress. Chemosphere, 2007, 67, 2105-2114.

[14] Medina, M., Andrade, S., Faugeron, S., Lagos, N. et al., Biodiversity of rocky intertidal benthic communities associated with copper mine tailing discharges in northern Chile. Mar. Pollut. Bull. 2005, 50, 396-409.

[15] Hall, A., Copper accumulation in copper-tolerant and non-tolerant populations of the marine fouling alga Ectocarpus siliculosus (Dillw.) Lyngbye. Bot. Mar. 1981, 24, 223-228.

[16] Hall, A., Heavy metal Co-tolerance in a copper tolerant population of the marine fouling alga, Ectocarpus siliculosus (Dillw.) Lyngbye. New Phytol. 1980, 85, 73-78.

[17] Russel, G., Morris, O. P., Copper tolerance in marine fouling alga Ectocarpus siliculosus. Nature 1970, 228, 288-289.

[18] Morris, O. P., Russel, G., Inter-specific differences in response to copper by natural populations of Ectocarpus. J. Brit. Phycol. 1974, 9, 269-272.

[19] Puig, S., Andres-Colas, N., Garcia-Molina, A., Penarrubia, L., Copper and iron homeostasis in Arabidopsis: responses to metal deficiencies, interactions and biotechnological applications. Plant Cell Environ. 2007, 30, 271-290. 
[20] Küpper, H., Kroneck, P. M. H., Heavy metal uptake by plants and cyanobacteria. Met. lons Biol. Syst. 2005, 44, 97-144.

[21] Hall, J. L., Cellular mechanisms for heavy metal detoxification and tolerance. J. Exp. Bot. 2002, 53, 1-11.

[22] Cobbett, C., Goldsbrough, P., Phytochelatins and metallothioneins: roles in heavy metal detoxification and homeostasis. Annu. Rev. Plant Biol. 2002, 53, 159-182.

[23] Clemens, S., Toxic metal accumulation, responses to exposure and mechanisms of tolerance in plants. Biochimie 2006, 88, 1707-1719.

[24] Andrés-Colás, N., Sancenón, V., Rodríguez-Navarro, S., Mayo, S. et al., The Arabidopsis heavy metal P-type ATPase HMA5 interacts with metallochaperones and functions in copper detoxification of roots. Plant J. 2006, 45, 225-236.

[25] Pawlik-Skowronska, B., Pirszel, J., Brown, M. T., Concentrations of phytochelatins and glutathione found in natural assemblages of seaweeds depend on species and metal concentrations of the habitat. Aquat. Toxicol. 2007, 83, 190-199.

[26] Morris, C. A., Nicolaus, B., Sampson, V., Harwood, J. L. et al., Identification and characterization of a recombinant metallothionein protein from a marine alga, Fucus vesiculosus. Biochem. J. 1999, 338, 553-560.

[27] Toth, G., Pavia, H., Lack of phlorotannin induction in the brown seaweed Ascophyllum nodosum in response to increased copper concentrations. Mar. Ecol. Progr. Ser. 2000, 192, 119-126.

[28] Salgado, L. T., Andrade, L. R., Filho, G. M. A., Localization of specific monosaccharides in cells of the brown alga Padina gymnospora and the relation to heavy-metal accumulation. Protoplasma 2005, 225, 123-128.

[29] Sueur, S., Van Den Berg, C. M. G., Riley, J. P., Measurement of the metal complexing ability of exudates of marine macroalgae. Limnol. Oceanogr. 1982, 27, 536-543.

[30] Karez, C. S., Pereira, R. C., Metal contents in polyphenolic fractions extracted from brown alga Padina gymnospora. Bot. Mar. 1995, 38, 151-155.

[31] Andrade, L. R., Farina, M., Amado Filho, G., Role of Padina gymnospora (Dictyotales, Phaeophyceae) cell walls in cadmium accumulation. Phycologia 2002, 41, 39-48.

[32] Contreras, L., Moenne, A., Correa, J. A., Antioxidant responses in Scytosiphon lomentaria (Phaeophyceae) inhabiting copper-enriched coastal environments. J. Phycol. 2005, 41, 1184-1195.

[33] Pinto, E., Sigaud-Kutner, T. C. S., Leitao, M. A. S., Okamoto, O. K. et al., Heavy metal-induced stress in algae. J. Phycol. 2003, 39, 1008-1018.

[34] Ritter, A., Goulitquer, S., Salaün, J.-P., Tonon, T. et al., Copper stress induces biosynthesis of octadecanoid and eicosanoid oxygenated derivatives in the brown algal kelp Laminaria digitata. New Phytol. 2008, 180, 809-821.

[35] Baldauf, S. L., The deep roots of eukaryotes. Science, 2003, 300, 1703-1706.

[36] Küpper, F. C., Carpenter, L. J., McFiggans, G. B., Palmer, C. J. et al., lodide accumulation provides kelp with an inorganic antioxidant impacting atmospheric chemistry. Proc. Natl. Acd. Sci. USA 2008, 105, 6954-6958.

[37] Charrier, B., Coelho, S. M., Le Bail, A., Tonon, T. et al., Development and physiology of the brown alga Ectocarpus siliculosus: two centuries of research. New Phytol. 2008, 177, 319-332.

[38] Requejo, R., Tena, M., Proteome analysis of maize roots reveals that oxidative stress is a main contributing factor to plant arsenic toxicity. Phytochem. 2005, 66, 1519-1528.

[39] Sarry, J.-E., Kuhn, L., Ducruix, C., Lafaye, A. et al., The early responses of Arabidopsis thaliana cells to cadmium exposure explored by protein and metabolite profiling analyses. Proteomics 2006, 6, 2180-2198.

[40] Smith, A. P., Deridder, B. P., Guo, W. J., Seeley, E. H. et al., Proteomic analysis of Arabidopsis glutathione S-transferases from benoxacor- and copper-treated seedlings. J. Biol. Chem. 2004, 279, 26098-26104.

[41] Kung, C.-C. S., Huang, W.-N., Huang, Y.-C., Yeh, K.-C., Proteomic survey of copper-binding proteins in Arabidopsis roots by immobilized metal affinity chromatography and mass spectrometry. Proteomics 2006, 6, 2746-2758.

[42] Bona, E., Marsano, F., Cavaletto, M., Berta, G., Proteomic characterization of copper stress response in Cannabis sativa roots. Proteomics 2007, 7, 1121-1130.

[43] Contreras, L., Ritter, A., Dennett, G., Boehmwald, F. et al., Two-dimesional gel electrophoresis analyses of brown algal protein extracts. J. Phycol. 2008, 44, 1315-1321.

[44] Starr, R. C., Zeikus, J. A., UTEX-the culture collection of algae at the university of Texas at Austin 1993 list of cultures. J. Phycol. 1993, 29, 1-106.

[45] Le Bail, A., Dittami, S., De Franco, P.-O., Rousvoal, S. et al., Normalisation genes for expression analyses in the brown alga model Ectocarpus siliculosus. BMC Plant Mol. Biol. 2008, 9, 75.

[46] Bradford, M. M., Rapid and sensitive method for quantitation of microgram quantities of protein utilizing principle of protein-dye binding. Anal. Biochem. 1976, 72, 248-254.

[47] Colin, C., Leblanc, C., Michel, G., Wagner, E. et al., Vanadium-dependent iodoperoxidases in Laminaria digitata, a novel biochemical function diverging from brown algal bromoperoxidases. J. Biol. Inorg. Chem. 2005, 10, 156-166.

[48] Cid, A., Herrero, C., Torres, E., Abalde, J., Copper toxicity on the marine microalga Phaeodactylum tricornutum: effects on photosynthesis and related parameters. Aquat. Toxicol. 1995, 31, 165-174.

[49] Xiang, C., Oliver, D. J., Glutathione metabolic genes coordinately respond to heavy metals and jasmonic acid in Arabidopsis. Plant Cell 1998, 10, 1539-1550.

[50] Meister, A., Anderson, M. E., Glutathione. Annu. Rev. Biochem. 1983, 52, 711-760.

[51] Alscher, R. G., Biosynthesis and antioxidant function of glutathione in plants. Physiol. Plant 1989, 77, 457-464.

[52] De Franco, P.-O., Rousvoal, S., Tonon, T., Boyen, C., Whole genome survey of the glutathione transferase family in the brown algal model Ectocarpus siliculosus. Marine Genomics 2009, 1, 135-148. 
[53] Lee, S.-E., Yoo, D.-H., Son, J., Cho, K., Proteomic evaluation of cadmium toxicity on the midge Chironomus riparius Meigen larvae. Proteomics 2006, 6, 945-957.

[54] Liao, M., Hedley, M., Woolley, D., Brooks, R. et al., Copper uptake and translocation in chicory (Cichorium intybus L. cv Grasslands Puna) and tomato (Lycopersicon esculentum Mill. cv Rondy) plants grown in NFT system. II. The role of nicotianamine and histidine in xylem sap copper transport. Plant Soil 2000, 223, 245-254.

[55] Vierling, E., The roles of heat shock proteins in plants. Annu. Rev. Plant Physiol. Plant Mol. Biol. 1991, 42, 579-620.

[56] Lindquist, S., Craig, E. A., The heat-shock proteins. Annu. Rev. Gen. 1988, 22, 631-677.

[57] Pearl, L. H., Prodromou, C., Structure and mechanism of the Hsp90 molecular chaperone machinery. Ann. Rev. Biochem. 2006, 75, 271-294.

[58] Panaretakis, T., Joza, N., Modjtahedi, N., Tesniere, A. et al., The co-translocation of ERp57 and calreticulin determines the immunogenicity of cell death. Cell Death Differ. 2008, 15, 1499-1509.

[59] Nadimpalli, R., Yalpani, N., Johal, G. S., Simmons, C. R., Prohibitins, stomatins, and plant disease response genes compose a protein superfamily that controls cell proliferation, ion channel regulation, and death. J. Biol. Chem. 2000, 275, 29579-29586.

[60] Braun, R. J., Zischka, H., Mechanisms of Cdc48/VCP-mediated cell death - from yeast apoptosis to human disease. Biochim. Biophys. Acta Mol. Cell Res. 2008, 1783, 1418-1435.

[61] Rijstenbil, J. W., Effects of UVB radiation and salt stress on growth, pigments and antioxidative defence of the marine diatom Cylindrotheca closterium. Mar. Ecol. Prog. Ser. 2003, 254, 37-47.

[62] Clendennen, S. K., Zimmerman, R. C., Powers, D. A., Alberte, R. S., Photosynthetic response of the giant kelp Macrocystis pyrifera (phaeophyceae) to ultraviolet radiation. J. Phycol. 1996, 32, 614-620.

[63] Halliwell, B., Gutterridge, J., Oxygen toxicity, oxygen radicals, transition metals and disease. Biochem. J. 1984, 219, $1-14$.
[64] Yruela, I., Alfonso, M., Baron, M., Picorel, R., Copper effect on the protein composition of photosystem II. Physiol. Plant 2000, 110, 551-557.

[65] Bernal, M., Roncel, M., Ortega, J. M., Picorel, R. et al., Copper effect on cytochrome b559 of photosystem II under photoinhibitory conditions. Physiol. Plant 2004, 120, 686-694.

[66] Henmi, T., Miyao, M., Yamamoto, Y., Release and reactiveoxygen-mediated damage of the oxygen-evolving complex subunits of PSIl during photoinhibition. Plant Cell Physiol. 2004, 45, 243-250.

[67] Rocak, S., Linder, P., DEAD-box proteins: the driving forces behind RNA metabolism. Nat. Rev. Mol. Cell. Biol. 2004, 5, 232-241.

[68] Sanan-Mishra, N., Pham, X. H., Sopory, S. K., Tuteja, N., Pea DNA helicase 45 overexpression in tobacco confers high salinity tolerance without affecting yield. Proc. Natl. Acad. Sci. 2005, 102, 509-514.

[69] Luo, Y., Liu, Y. B., Dong, Y. X., Gao, X.-Q. et al., Expression of a putative alfalfa helicase increases tolerance to abiotic stress in Arabidopsis by enhancing the capacities for ROS scavenging and osmotic adjustment. J. Plant Physiol. 2009, $66,385-394$.

[70] Leblanc, C., Colin, C., Cosse, A., Delage, L. et al., lodine transfers in the coastal marine environment: the key role of brown algae and of their vanadium-dependent haloperoxidases. Biochimie 2006, 88, 1773-1785.

[71] Küpper, F. C., Schweigert, N., Ar Gall, E., Legendre, J.-M. et al., lodine uptake in Laminariales involves extracellular, haloperoxidase-mediated oxidation of iodide. Planta 1998, 207, 163-171.

[72] Verhaeghe, E., Fraysse, A., Guerquin-Kern, J.-L., Wu, T.-D. et al., Microchemical imaging of iodine distribution in the brown alga Laminaria digitata suggests a new mechanism for its accumulation. J. Biol. Inorg. Chem. 2008, 13, 257-269.

[73] Roeder, V., Collen, J., Rousvoal, S., Corre, E. et al., Identification of stress gene transcripts in Laminaria digitata (phaeophyceae) protoplast cultures by Expressed Sequence Tag analysis. J. Phycol. 2005, 41, 1227-1235. 